\title{
Reclassification of Lactobacillus brevis strains LMG 11494 and LMG 11984 as Lactobacillus parabrevis sp. nov.
}

\author{
Marc Vancanneyt, ${ }^{1}$ Sabri M. Naser, ${ }^{1,2}$ Katrien Engelbeen, ${ }^{1}$ \\ Marjan De Wachter, ${ }^{1}$ Roel Van der Meulen, ${ }^{3}$ Ilse Cleenwerck, ${ }^{1}$ Bart Hoste, ${ }^{1}$ \\ Luc De Vuyst ${ }^{3}$ and Jean Swings ${ }^{1,2}$ \\ 1,2BCCM/LMG Bacteria Collection ${ }^{1}$ and Laboratory of Microbiology ${ }^{2}$, Faculty of Sciences, \\ Ghent University, K. L. Ledeganckstraat 35, B-9000 Ghent, Belgium \\ ${ }^{3}$ Research Group of Industrial Microbiology, Fermentation Technology and Downstream \\ Processing (IMDO), Department of Applied Biological Sciences, Vrije Universiteit Brussel \\ (VUB), Pleinlaan 2, B-1050 Brussels, Belgium
}

Correspondence Marc Vancanneyt Marc.Vancanneyt@UGent.be

\begin{abstract}
A polyphasic study revealed taxonomic heterogeneity among reference strains of the species Lactobacillus brevis. Representative strains of $L$. brevis and related taxa were investigated by partial sequence analysis of the housekeeping gene encoding the alpha-subunit of phenylalanyl-tRNA synthase (pheS). Species-specific clusters were delineated for all taxa studied except for two L. brevis strains, LMG 11494 and LMG 11984, respectively isolated from cheese and wheat, which occupied a distinct position. Their phylogenetic affiliation was determined using $16 \mathrm{~S}$ rRNA gene sequence analysis and it was found that both strains (with $99.9 \%$ gene sequence similarity between them) belonged to the Lactobacillus buchneri group, with nearest neighbours Lactobacillus hammesii and L. brevis (gene sequence similarities of $99 \cdot 2$ and $98 \cdot 1 \%$, respectively). Further genotypic and phenotypic studies, including fluorescent amplified fragment length polymorphism, DNA-DNA hybridization and DNA G $+\mathrm{C}$ content, clearly demonstrated that the two strains represent a single novel taxon for which the name Lactobacillus parabrevis sp. nov. is proposed (type strain LMG $11984^{\top}=$ ATCC $53295^{\top}$ ).
\end{abstract}

Lactobacillus brevis strains are frequently isolated from the spoilage microbiota in wine and beer fermentations, but also occur in fermented foods and feed such as sourdoughs, sour starch, cheeses, olives and silage (Stiles \& Holzapfel, 1997). Identification of strains of L. brevis using conventional phenotypic methods often leads to ambiguous results (Kandler \& Weiss, 1986; Pot et al., 1994). Molecular approaches have proved to be much more reliable (Vogel et al., 1994; Sohier et al., 1999; Guarneri et al., 2001) and have enabled 'L. brevis-like' isolates to be assigned to novel taxa such as Lactobacillus acidifarinae, Lactobacillus hammesii, Lactobacillus spicheri and Lactobacillus zymae (Meroth et al., 2004; Valcheva et al., 2005; Vancanneyt et al., 2005). In the present study, reference strains of L. brevis available from the BCCM/LMG Bacteria Collection (http://www.belspo. be/bccm/lmg.htm) were screened genotypically and the

Abbreviation: FAFLP, fluorescent amplified fragment length polymorphism.

The GenBank/EMBL/DDBJ accession numbers for the 16S rRNA gene sequences of strains LMG 11494 and LMG $11984^{\top}$ are AM158250 and AM158249, respectively. results demonstrated that two strains, LMG 11494 and LMG 11984, occupied a distinct position. Further genomic and phenotypic research revealed that these strains represent a single novel species.

Strain LMG 11494 (=NCFB 1058) was isolated from farmhouse red Cheshire cheese and was originally deposited in the NCFB culture collection as L. brevis by A. Hayward in 1957. Strain LMG 11984 (= ATCC 53295) was isolated from wheat and deposited in the ATCC as L. brevis (originally named Sporolactobacillus sp.) by M. Spiller in 1992. It is a patent strain used for the production of leavening barm (Spiller, 1987). Both strains and related reference strains were cultivated and maintained on de Man, Rogosa and Sharpe (MRS) agar medium ( $\mathrm{pH} 6 \cdot 5$; de Man et al., 1960) and incubated at $30{ }^{\circ} \mathrm{C}$ for $24-48 \mathrm{~h}$, unless otherwise indicated.

Sequence analysis of the phenylalanyl-tRNA synthase alphasubunit ( $p h e S$ ) housekeeping gene has been proved to be a robust approach for the identification of enterococci (Naser et al., 2005a). Furthermore, the method is an excellent tool for delineating novel taxa (Naser et al., 2005b; Švec et al., 
2005a, b). In the present study, this methodology was applied to lactobacilli of the Lactobacillus buchneri species group. The primer sequences, amplification conditions and sequencing reactions performed were as described by Naser et al. (2005a). As found previously for enterococci, a speciesspecific grouping was obtained, as all Lactobacillus species studied formed distinct clusters (data not shown). Only two L. brevis strains, LMG 11494 and LMG 11984, showed an aberrant position. The neighbour-joining tree depicted in Fig. 1 (based upon comparison of partial sequences of $309 \mathrm{bp}$ ) revealed the relatedness between strains LMG 11494 and LMG 11984 and type strains of related taxa and showed that the two strains under study constituted a distinct cluster with a gene sequence similarity of $97 \%$. Nearest neighbours were the type strains of $L$. acidifarinae, L. hammesii, $L$. spicheri and L. zymae, with sequence similarities in a significantly lower range of $85-87 \%$. L. brevis and other taxa of the L. buchneri species group were more distantly related, with sequence similarities below $82 \%$.

The phylogenetic position of strains LMG 11494 and LMG 11984 was further determined by complete 16S rRNA gene sequence analysis. DNA for $16 \mathrm{~S}$ rRNA gene sequencing was prepared by heating one or two colonies at $95^{\circ} \mathrm{C}$ for $15 \mathrm{~min}$ in $20 \mu \mathrm{l}$ lysis buffer containing $0.25 \%(\mathrm{w} / \mathrm{v})$ SDS and $0.05 \mathrm{M} \mathrm{NaOH}$. Following lysis, $180 \mu \mathrm{l}$ distilled water was added to the lysate. 16S rRNA genes were amplified using oligonucleotide primers complementary to highly conserved regions of bacterial $16 \mathrm{~S}$ rRNA genes. The forward primer was 5'-AGAGTTTGATCCTGGCTCAG-3' (hybridizing at positions 8-27, according to the Escherichia coli numbering system) and the reverse primer was 5'-AAGGAGGTGATCCAGCCGCA-3' (hybridizing at positions 1541-1522). PCR products were purified by using a NucleoFast 96 PCR clean-up kit (Macherey Nagel). Sequencing reactions were performed by using a BigDye Terminator Cycle sequencing

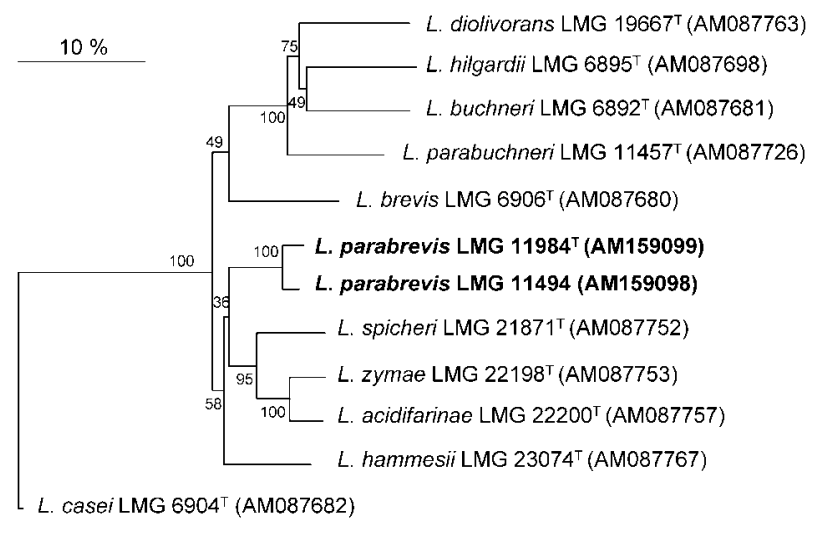

Fig. 1. Neighbour-joining tree based on the partial pheS gene sequences of $L$. parabrevis and other reference species belonging to the $L$. buchneri group. Bootstrap percentages after 500 simulations are shown. Lactobacillus casei LMG $6904^{\top}$ was included as an outgroup. Bar, $10 \%$ difference in nucleotide sequence. kit (Applied Biosystems) and purified by using a Montage $\mathrm{SEQ}_{96}$ sequencing reaction cleanup kit (Millipore). Sequencing was performed using an ABI Prism 3100 Genetic Analyzer (Applied Biosystems). The eight sequencing primers used are listed in Coenye et al. (1999). Sequence assembly was performed using the AUTOASSEMBLER program (Applied Biosystems). Sequences were aligned with sequences retrieved from GenBank using CLUSTAL_X (Thompson et al., 1997). Phylogenetic analyses and bootstrap analysis (500 replicates) were subsequently performed using the BioNumerics 4.01 software package (Applied Maths). A phylogenetic tree was constructed using the neighbour-joining method (Fig. 2; Saitou \& Nei, 1987) and unknown bases were discarded for the analyses. Comparison of the newly determined complete sequences for strains LMG 11494 and LMG 11984 (continuous stretches of $1518 \mathrm{bp}$ ) revealed a sequence similarity of $99.9 \%$. The tree topology obtained with the neighbour-joining method was evaluated and confirmed by maximum parsimony analysis using BioNumerics (data not shown). Comparison with deposited sequences available in the EMBL database classified strains LMG 11494 and LMG 11984 as part of the L. buchneri group (Schleifer \& Ludwig, 1995) with the nearest neighbours ( $>97 \%$ sequence similarity) L. hammesii and L. brevis, showing sequence similarities of $99 \cdot 2$ and $98 \cdot 1 \%$, respectively.

Strains LMG 11494 and LMG 11984 were further screened using PAGE of whole-cell proteins. Whole-cell protein extracts were prepared and SDS-PAGE was performed as described by Pot et al. (1994). Densitometric analysis, normalization and interpolation of protein profiles and a

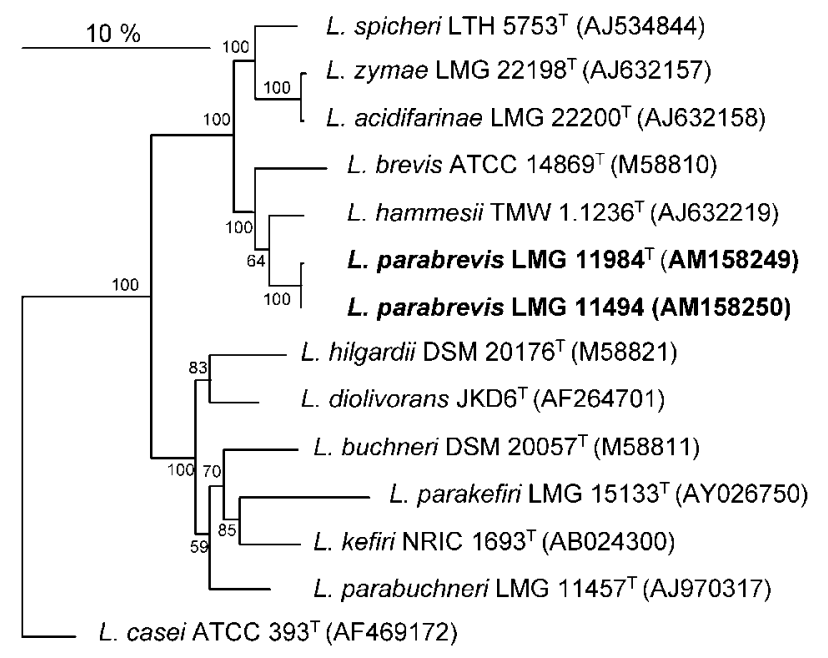

Fig. 2. Distance matrix tree showing the phylogenetic relationships of $L$. parabrevis and other reference species belonging to the $L$. buchneri group, based on 16S rRNA gene sequence comparisons. L. casei ATCC $393^{\top}$ was used as the outgroup. Bootstrap probability values (percentages of 500 tree replications) are indicated at branch-points. Bar, 10\% difference in nucleotide sequence. 
numerical analysis were performed by using the GELCOMPAR software package, versions 3.1 and 4.0, respectively (Applied Maths). After comparison with an in-house database containing profiles of nearly all recognized lactic acid bacteria, the two strains could not be distinguished from representatives of $L$. brevis. Phylogenetically related species, such as $L$. acidifarinae, L. hammesii, L. spicheri and L. zymae, occupied distinct positions (data not shown). Although this approach is very valuable for species identification of most lactic acid bacteria, some closely related species are not distinguished by this method, as has been shown previously within the Lactobacillus plantarum species group (Torriani et al., 2001) and the Lactobacillus acidophilus species group (Gancheva et al., 1999).

Strains LMG 11494 and LMG 11984 and a representative set of reference strains were investigated by a genotypic screening approach using fluorescent amplified fragment length polymorphism (FAFLP) fingerprinting of whole genomes. FAFLP fingerprinting was performed as described by Thompson et al. (2001) with the following modifications: EcoRI/TaqI was used as the restriction enzyme combination and the primer combination E01/T01 (both having an adenosine extension at the $3^{\prime}$-end) was applied for selective PCR. The resulting electrophoretic patterns were tracked and normalized using GENESCAN 3.1 software (Applera). Normalized tables of peaks, containing fragments of 50 $536 \mathrm{bp}$, were transferred into the BioNumerics software package, version 3.5, and the computer-generated fingerprints were added to an existing database of FAFLP fingerprints of lactic acid bacteria held at the BCCM/LMG Bacteria Collection. For numerical analysis, the region between the 75 and $500 \mathrm{bp}$ bands of the internal standard were used. Similarity was calculated using the Dice coefficient and clustering was performed using the UPGMA algorithm. The dendrogram obtained from the analysis (Fig. 3) confirmed the distinct taxonomic position of strains LMG 11494 and LMG 11984.
DNA G + C contents were determined for strains LMG 11494 and LMG 11984. DNA was extracted from 0.75$1.25 \mathrm{~g}$ (wet weight) using the protocol described by Gevers et al. (2001), using a combination of glass beads and enzymes, but with the following modifications. Volumes were increased tenfold for application on a large scale. SDStreated cells were vortexed with beads for $30 \mathrm{~s}$. After addition of $16.5 \mathrm{ml}$ buffer $(10 \mathrm{mM}$ Tris/HCl, $100 \mathrm{mM}$ EDTA, pH 8.0) and $5 \mathrm{ml} 5 \mathrm{M} \mathrm{NaCl}$ and gentle mixing, the suspension was incubated at $65^{\circ} \mathrm{C}$ for $10 \mathrm{~min}$. Subsequent chloroform/isoamylalcohol extraction, precipitation, spooling of DNA on a glass rod, washing with ethanol and RNase treatment were performed as described by Marmur (1961). For determination of the DNA G + C content, DNA was enzymically degraded into nucleosides as described by Mesbah et al. (1989). The nucleoside mixture was then separated by HPLC using a SymmetryShield RP8 column (Waters) maintained at $37^{\circ} \mathrm{C}$. The solvent was $0.02 \mathrm{M}$ $\left(\mathrm{NH}_{4} \mathrm{H}_{2} \mathrm{PO}_{4}(\mathrm{pH} 4 \cdot 0)\right.$ with $1.5 \%$ acetonitrile. Nonmethylated lambda phage DNA (Sigma) was used as the calibration reference. DNA G $+\mathrm{C}$ contents of strains LMG 11494 and LMG 11984 were $49 \mathrm{~mol} \%$. This value is lower than the value of $52.6 \mathrm{~mol} \%$ determined for the type strain of $L$. hammesii and significantly higher than the value of $46 \mathrm{~mol} \%$ determined for the type strain of L. brevis (Valcheva et al., 2005).

DNA-DNA hybridizations were performed between strains LMG 11494 and LMG 11984 and the type strains of L. brevis and L. hammesii (DNA was prepared as described above). Strain LMG 11984 was further hybridized with the type strains of L. acidifarinae, L. spicheri and L. zymae. The microplate method was used as described by Ezaki et al. (1989) and Goris et al. (1998), using a HTS7000 Bio Assay Reader (Perkin Elmer) for fluorescence measurements. Biotinylated single-stranded DNA (ssDNA) was hybridized with unlabelled ssDNA, which was bound non-covalently to microplate wells. Hybridizations were performed at $40{ }^{\circ} \mathrm{C}$ in

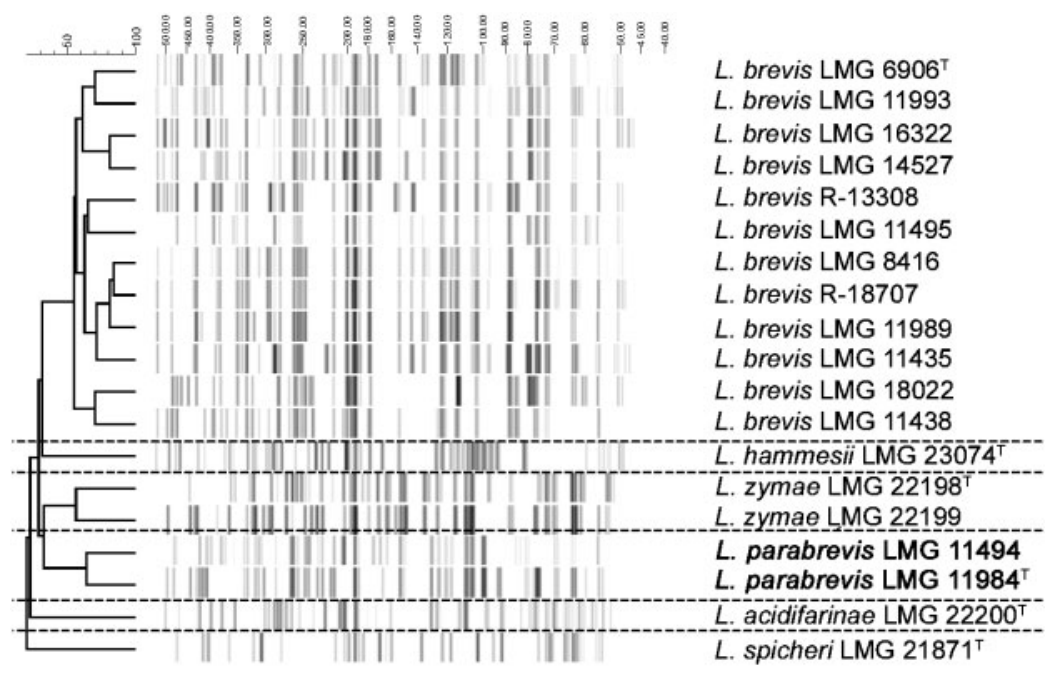

Fig. 3. FAFLP patterns and corresponding dendrogram, derived from the UPGMA linkage of Dice coefficients (expressed as a percentage value for convenience) of $L$. parabrevis strains and related reference strains. 
hybridization mixture $(2 \times$ SSC, $5 \times$ Denhardt's solution, $2.5 \%$ dextran sulphate, $50 \%$ formamide, $100 \mu \mathrm{g}$ denatured salmon sperm DNA ml ${ }^{-1}$ and $1.25 \mu \mathrm{g}$ biotinylated probe DNA $\mathrm{ml}^{-1}$ ). The DNA-DNA relatedness percentages presented are mean values based on four independent hybridization experiments. Reciprocal reactions (e.g. $\mathrm{A} \times \mathrm{B}$ and $\mathrm{B} \times \mathrm{A}$ ) were performed and are also considered as independent hybridization experiments. Strains LMG 11494 and LMG 11984 displayed hybridization values of 35 and $40 \%$, respectively, with the type strain of $L$. hammesii and 7 and $8 \%$, respectively, with the type strain of L. brevis. Strain LMG 11984 yielded values in the range of $5-18 \%$ with the type strains of L. acidifarinae, L. spicheri and L. zymae. The DNA-DNA hybridization value between strains LMG 11494 and LMG 11984 was $90 \%$, indicating a separate species status for the latter strains.

Growth characteristics and colony morphology were investigated on MRS agar after $24 \mathrm{~h}$ incubation at $37^{\circ} \mathrm{C}$ under aerobic conditions and are given below in the species description.

Conventional biochemical tests were performed as described by Vancanneyt et al. (2005) and carbohydrate fermentation tests were carried out using API $50 \mathrm{CHL}$ galleries following the manufacturer's instructions (bioMérieux). Metabolites from glucose were lactate, acetate and ethanol, as determined by HPLC (Waters). Isomers of Dand L-lactate were determined enzymically (R-Biopharm) and were in the ratio of $4: 6$ for strains LMG 11494 and LMG 11984. Strains LMG 11494 and LMG 11984 were differentiated from their nearest neighbour L. hammesii by their ability to deaminate arginine and inability to produce acid from aesculin or mannitol (Valcheva et al., 2005). Features that differentiated the two strains from $L$. brevis were the abilities to produce acid from D-arabitol and methyl $\beta$-xyloside (Vancanneyt et al., 2005). Phenotypic data determined in the present study and by Vancanneyt et al. (2005) also revealed distinct features of the two novel strains which separate them from the more distantly related taxa L. acidifarinae, L. spicheri and L. zymae.

The overall results of the present study enable strains LMG 11494 and LMG 11984 to be assigned as representatives of a novel species, for which the name Lactobacillus parabrevis sp. nov. is proposed.

\section{Description of Lactobacillus parabrevis sp. nov.}

Lactobacillus parabrevis (pa.ra.bre'vis. Gr. prep. para like; L. masc. adj. brevis referring to the specific epithet of Lactobacillus brevis; N.L. masc. adj. parabrevis brevis-like, referring to L. brevis).

Cells are rod-shaped, occurring singly or in pairs and in chains, $1 \cdot 5-5 \mu \mathrm{m}$ in length and $0.9 \mu \mathrm{m}$ wide, Grampositive, catalase-negative, non-spore-forming and nonmotile. After $24 \mathrm{~h}$, colonies are beige, circular with a smooth surface and approximately $1 \mathrm{~mm}$ in diameter. Growth occurs at $15{ }^{\circ} \mathrm{C}$, but not at $45^{\circ} \mathrm{C}$. Growth occurs at $6 \% \mathrm{NaCl}$. Facultatively anaerobic and produces DL-lactic acid heterofermentatively with acetic acid and ethanol as other metabolites from glucose. Gas is produced from glucose and gluconate. Arginine is deaminated. All strains produce acid from L-arabinose, D-arabitol, gluconate, $N$-acetylglucosamine, D-glucose, D-fructose, maltose, ribose, Dxylose and methyl $\beta$-xyloside. All strains test negative for acid production from D-arabinose, L-arabitol, adonitol, amygdalin, arbutin, cellobiose, dulcitol, aesculin, erythritol, $\mathrm{D}$ - and L-fucose, $\beta$-gentiobiose, 2 - and 5-ketogluconate, glycerol, glycogen, inositol, inulin, D-lyxose, mannitol, Dmannose, methyl $\alpha$-D-mannoside, melezitose, melibiose, D-raffinose, rhamnose, sucrose, salicin, starch, sorbitol, Lsorbose, D-tagatose, trehalose, D-turanose, xylitol and L-xylose. Acid production from galactose, methyl $\alpha$-Dglucoside and lactose is strain-dependent. The $\mathrm{G}+\mathrm{C}$ content of DNA is $49 \mathrm{~mol} \%$.

The type strain, LMG $11984^{\mathrm{T}}\left(=\mathrm{ATCC} 53295^{\mathrm{T}}\right)$, was isolated from wheat. A reference strain, LMG 11494 ( = NCFB 1058), has also been isolated from cheese.

\section{Acknowledgements}

This research was supported by the Prime Minister's Services - Federal Office for Scientific, Technical and Cultural Affairs, Belgium, in particular the action to stimulate the use of and cooperation with the Belgian Coordinated Collections of Microorganisms (contract no. C3/00/17). S. M. N. acknowledges a PhD scholarship from the Ministry of Education and Higher Education.

\section{References}

Coenye, T., Falsen, E., Vancanneyt, M., Hoste, B., Govan, J. R. W., Kersters, K. \& Vandamme, P. (1999). Classification of Alcaligenes faecalis-like isolates from the environment and human clinical samples as Ralstonia gilardii sp. nov. Int J Syst Bacteriol 49, 405-413.

de Man, J. C., Rogosa, M. \& Sharpe, M. E. (1960). A medium for the cultivation of lactobacilli. J Appl Bacteriol 23, 130-135.

Ezaki, T., Hashimoto, Y. \& Yabuuchi, E. (1989). Fluorometric deoxyribonucleic acid-deoxyribonucleic acid hybridization in microdilution wells as an alternative to membrane filter hybridization in which radioisotopes are used to determine genetic relatedness among bacterial strains. Int J Syst Bacteriol 39, 224-229.

Gancheva, A., Pot, B., Vanhonacker, K., Hoste, B. \& Kersters, K. (1999). A polyphasic approach towards the identification of strains belonging to Lactobacillus acidophilus and related species. Syst Appl Microbiol 22, 573-585.

Gevers, D., Huys, G. \& Swings, J. (2001). Applicability of rep-PCR fingerprinting for identification of Lactobacillus species. FEMS Microbiol Lett 205, 31-36.

Goris, J., Suzuki, K., De Vos, P., Nakase, T. \& Kersters, K. (1998). Evaluation of a microplate DNA-DNA hybridization method compared with the initial renaturation method. Can J Microbiol 44, 1148-1153.

Guarneri, T., Rossetti, L. \& Giraffa, G. (2001). Rapid identification of Lactobacillus brevis using the polymerase chain reaction. Lett Appl Microbiol 33, 377-381. 
Kandler, O. \& Weiss, N. (1986). Genus Lactobacillus Beijerinck 1901, $212^{\mathrm{AL}}$. In Bergey's Manual of Systematic Bacteriology, vol. 2, pp. 1209-1234. Edited by P. H. A. Sneath, N. S. Mair \& J. G. Holt. Baltimore: Williams \& Wilkins.

Marmur, J. (1961). A procedure for the isolation of deoxyribonucleic acid from microorganisms. J Mol Biol 3, 208-218.

Meroth, C. B., Hammes, W. P. \& Hertel, C. (2004). Characterisation of the microbiota of rice sourdoughs and description of Lactobacillus spicheri sp. nov. Syst Appl Microbiol 27, 151-159.

Mesbah, M., Premachandran, U. \& Whitman, W. B. (1989). Precise measurement of the $\mathrm{G}+\mathrm{C}$ content of deoxyribonucleic acid by highperformance liquid chromatography. Int J Syst Bacteriol 39, 159-167.

Naser, S. M., Thompson, F. L., Hoste, B., Gevers, D., Dawyndt, P., Vancanneyt, M. \& Swings, J. (2005a). Application of multilocus sequence analysis (MLSA) for rapid identification of Enterococcus species based on rpoA and pheS genes. Microbiology 151, 2141-2150.

Naser, S. M., Vancanneyt, M., De Graef, E. \& 8 other authors (2005b). Enterococcus canintestini sp. nov., from faecal samples of healthy dogs. Int J Syst Evol Microbiol 55, 2177-2182.

Pot, B., Vandamme, P. \& Kersters, K. (1994). Analysis of electrophoretic whole-organism protein fingerprints. In Chemical Methods in Prokaryotic Systematics, pp. 493-521. Edited by M. Goodfellow \& A. G. O’Donnell. Chichester: Wiley.

Saitou, N. \& Nei, M. (1987). The neighbor-joining method: a new method for reconstructing phylogenetic trees. Mol Biol Evol 4, 406-425.

Schleifer, K. H. \& Ludwig, W. (1995). Phylogeny of the genus Lactobacillus and related genera. Syst Appl Microbiol 18, 461-467.

Sohier, D., Coulon, J. \& Lonvaud-Funel, A. (1999). Molecular identification of Lactobacillus hilgardii and genetic relatedness with Lactobacillus brevis. Int J Syst Bacteriol 49, 1075-1081.

Spiller, M. A. (1987). A mixture of a Lactobacillus brevis and Saccharomyces dairensis for preparing leavening barm. US Patent 4,666,719. 19 May 1987, US Patent Office.
Stiles, M. E. \& Holzapfel, W. H. (1997). Lactic acid bacteria of foods and their current taxonomy. Int J Food Microbiol 36, 1-29.

Švec, P., Vancanneyt, M., Devriese, L. A., Naser, S. M., Snauwaert, C., Lefebvre, K., Hoste, B. \& Swings, J. (2005a). Enterococcus aquimarinus sp. nov., isolated from sea water. Int $J$ Syst Evol Microbiol 55, 2183-2187.

Švec, P., Vancanneyt, M., Koort, J., Naser, S. M., Hoste, B., Vihavainen, E., Vandamme, P., Swings, J. \& Björkroth, J. (2005b). Enterococcus devriesei sp. nov., associated with animal sources. Int J Syst Evol Microbiol 55, 2479-2484.

Thompson, J. D., Gibson, T. J., Plewniak, F., Jeanmougin, F. \& Higgins, D. G. (1997). The CLUSTAL_X windows interface: flexible strategies for multiple sequence alignment aided by quality analysis tools. Nucleic Acids Res 25, 4876-4882.

Thompson, F. L., Hoste, B., Vandemeulebroecke, K. \& Swings, J. (2001). Genomic diversity amongst Vibrio isolates from different sources determined by fluorescent amplified fragment length polymorphism. Syst Appl Microbiol 24, 520-538.

Torriani, S., Clementi, F., Vancanneyt, M., Hoste, B., Dellaglio, F. \& Kersters, K. (2001). Differentiation of Lactobacillus plantarum, $L$. pentosus and L. paraplantarum species by RAPD-PCR and AFLP. Syst Appl Microbiol 24, 554-560.

Valcheva, R., Korakli, M., Onno, B., Prévost, H., Ivanova, I., Ehrmann, M. A., Dousset, X., Gänzle, M. G. \& Vogel, R. F. (2005). Lactobacillus hammesii sp. nov., isolated from French sourdough. Int J Syst Evol Microbiol 55, 763-767.

Vancanneyt, M., Neysens, P., De Wachter, M. \& 8 other authors (2005). Lactobacillus acidifarinae sp. nov. and Lactobacillus zymae sp. nov., from wheat sourdoughs. Int J Syst Evol Microbiol 55, 615-620.

Vogel, R. F., Bocker, G., Stolz, P. \& 7 other authors (1994). Identification of lactobacilli from sourdough and description of Lactobacillus pontis sp. nov. Int J Syst Bacteriol 44, 223-229. 